\title{
Cultural Crisis and Cultural Change in the Central Asian Muslim World: Looking at Social Change through the Lens of Art
}

\author{
David Makofsky \\ Ethnic Minorities Studies Center of China, China \\ Department of Anthropology, Queen's University Belfast, UK
}

Copyright $@ 2015$ Horizon Research Publishing All rights reserved.

\begin{abstract}
The dynamics of change in the Muslim world continue to be felt throughout Asia. This study presents the choices and challenges of the Uyghur community, which is in the Turkic Muslim area of Western China. There is enormous interest exhibited by contemporary social theorists and anthropologists (Shiner, Bourdieu) in the impact of the artist in shaping and being shaped by the 'culture' of the viewer. This impact deals with 'modernity and social change' as it is now occurring in Uyghur and Muslim society. A sample of Uyghur students discusses paintings by well-known contemporary Uyghur artists. There are also interviews with Uyghur faculty, artists, and editors, and interviews taken from Uyghur arts magazines. This discussion illustrates some of the critical issues facing Muslims in Central Asia. Typically, Uyghur 'national intellectual' leadership in the post-liberation period in China (1949-2010) was secularist and Muslim. The cultural changes that are part of the 'awakening' in Muslim Asia has challenged assumptions in contemporary cultural life, and produced some new explorations in both art and culture.
\end{abstract}

Keywords Muslim Culture, Uyghurs, Art

\section{Art and Culture in an Era of 'Culturally Modern' Islam}

Fifteen years ago, a well-known American sociologist with a Muslim background, Mansoor Moaddel, made the following observation, differentiating between the Muslim experiences under various settings. Moaddel contrasted two types of Islam [12, p.108-109]:

"From the nineteenth century on, Europeans and their Westernized allies in the Islamic countries have predominantly condemned Islam for its mistreatment of women. The responses of the Islamic scholars have been diverse. In Islamic fundamentalism, there is an outright attack on the West for its cultural 'decadence' and sexual promiscuity. Women are instructed to cover their bodies from head to toe with the exception of the face."

Moaddel continues: "In contrast, a group of modernist Muslim theologians, notably in India and Egypt around the turn of the century (1900), advanced a modernist exegesis of the Quran, arriving at an Islamic feminist conception of gender relations. These scholars championed women's rights to education and involvement in social affairs, questioned the existing restrictions on women, criticized men's attitudes and behavior toward women, and rejected polygamy."

Moaddel [12, p. 111] argued that liberalism in Egypt and India was made possible by the decline of the old Islamic elite. "As a result, the requisite social resources and space for new culture production were provided, a pluralistic discursive field emerged, and the growth of Islamic modernist discourse was made possible".

As Uyghurs with a Muslim national identity, Uyghur artists have been closely associated with the modernist movement both in artistic form (oil painting) and in the approach to subject matter. Leading writers in the social sciences discuss 'modernity' and its consequences in the sphere of culture and economy as involving the rise of an educated class, which would include the artist. This separation of the artist and the artisan and the creation of an artist as a member of the 'new class' is the significant element in 'cultural' change (Shiner [18] p. 249; Mudimbe, [13]).

\section{The Development of Modern Art in Xinjiang}

In Western tradition, the modern system of the arts developed in connection with a market for art among the growing middle class. For the Western industrial middle class system, Fine Arts were divided from the crafts to become an appropriate object of refined taste, and usefulness became a negative rather than a positive feature for a work of art. New institutions devoted to the arts, such as galleries, museums, concert halls and libraries came to be a central part 
of the new system. The aesthetic of cultural development and the character of the artist as a critic of modern society are derived from this tradition.

The analysis of change in Islamic values can be extended from Moaddel's vision of the Arab Middle East to the world of the Turkic Central Asian people, especially those in Western China. Instead of European colonialism and the Ottoman Empire/Persian Dynasties, we have the unique character of Russian and Chinese expansion into the steppes of Central Asia. Instead of capitalist colonialism and neo-liberal economics, there was the profoundly transformative Soviet and Chinese revolutions of the 20th century.

The world of Chinese Central Asia (the province of Xinjiang) and the rest of Central Asia may seem remote and unrelated to events in the Middle East, but the events in the center of the Moslem world have profound significance in the hinterland. In particular, identities such as Muslim-world secularist, Muslim liberal and Muslim conservative play important roles in attitudes and events in this Chinese province. In a militantly secularist society such as the People's Republic of China, such categories are not recognized. These categories are in fact relevant, and the ideas are expressed through art, although there are many difficulties in expression in this community in contemporary China,

As European technical innovations were introduced into the military in Imperial Russia and into the Qing Dynasty in China in the Nineteenth century, the largely nomadic and agrarian peoples of Central Asia were incorporated into these empires. Although the people themselves were Muslim and spoke a Turkish language rather than Russian or Chinese, the process of incorporation continued into the Nineteenth and Twentieth centuries, when the secular leaders of the Soviet Union and the People's Republic of China subdivided them into republics and autonomous administrative units. The secular national leadership in Moscow and Beijing had little use for either Islam or Turkish cultural identity.

There are many the difficulties involved doing field research in China, especially on sensitive topics. Severe penalties exist for Chinese citizens who say or write statements that might be construed as 'separatist' or hostile to the government. Even if these statements appear in Western newspapers or journals, the Chinese citizen is quite open to penalties. Police presence is visible throughout Xinjiang. A foreigner cannot legally be in China without registering his locality with the police, and this is especially true in Xinjiang. Despite these limitations, there is a good deal of research being carried out in China, and researchers use imaginative ways to overcome obstacles. Chinese scholars and institutions offer assistance, and the government and police often look the other way. It is not possible, given the uneasy relationship that exists between Uyghurs and Chinese in Xinjiang, China, to ask directly about Islam or national identity. Questions such as those about Muslim identity and religion developed by the Pew Foundation [13, 14] for international research could not be asked in contemporary
China

In this study, the goal was to infer difference in values based on responses to paintings. In the fall of 2013, Uyghur students and faculty at a major university in China were interviewed, and also Uyghur art students and artists in Urumqi, the capitol of Xinjiang province. Individuals were shown copies of paintings by well-known Uyghur modern artists. They were asked to comment on what made a painting 'Uyghur', what made a painting 'Muslim', and whether or not it was important that a Uyghur painting was 'Muslim'.

Additionally, there are discussions that appeared in Xinjiang Art [25 esp.60-65]. Some of the artists whose paintings are reviewed participated in a panel entitled "What Do Our Artists Say".

\section{What Makes a "Uyghur" Painting"?}

\section{3(a) the development of arts in Xinjiang}

There is a rich history of Uyghur art, beginning with the world famous Buddhist cave paintings of Dunhuang, and there is a history of calligraphy and miniature painting as well. Muslim practice had demanded a limited representation of the human form, and there were additional cultural limitations governing the representation of women. Uyghur artists often say that there was no Uyghur painting in the past; the practice of "limiting art to decoration" as one artist has said [25, p.63] eliminated the possibility of oil painting. There were handicrafts, embroidery, and carpet making; calligraphy was very important. The period of modern Uyghur art began after the Chinese revolution of 1949.

The People's Republic of China invested in the development of Western China's arts and arts education after its establishment in 1949. In 1952 Xinjiang College set up an art department and in 1958, on the foundations of this department, the Xinjiang School of Art was established. This became the Xinjiang College of Art. In the 1980s Xinjiang Normal University established a Department of Art, and these art schools continue to nurture many artists. At the same time Chinese schools of Art supported large numbers of ethnic minority artists in Xinjiang. Several dozen of these artists gradually became established, forming the backbone of Xinjiang's Fine Art scene. Specialist schools of drawing and painting were also founded, such as the Xinjiang School of Painting, which had a major influence on the development of Fine Art within the region. Uyghur television features ethnic culture and folklore. Museums, the exhibition place of the new system, are slowly being built.

\section{3(b) the subject matter and the Uyghur tradition}

Uyghur painters in the post 1949 period began to paint cultural events associated with Uyghur life. The most famous of these is the Uyghur Muqam. Muqam is the general term for a variety of musical arrangements widespread among the communities in Xinjiang. As described by Rachel Harris [8, 9], Xinjiang's Uyghur 
Muqam is a composite of songs, dances, folk and classical music characterized by diversity of content, dance styles, musical morphology and instruments used. The muqam has been performed throughout the province regularly for centuries, although during the Twentieth century the frequency of performances greatly diminished. Because the Xinjiang region has always been marked by a high degree of cultural exchange between East and West, and because of its location at the hub of the Silk Road, the muqam incorporates themes from many of the peoples of Central Asia.

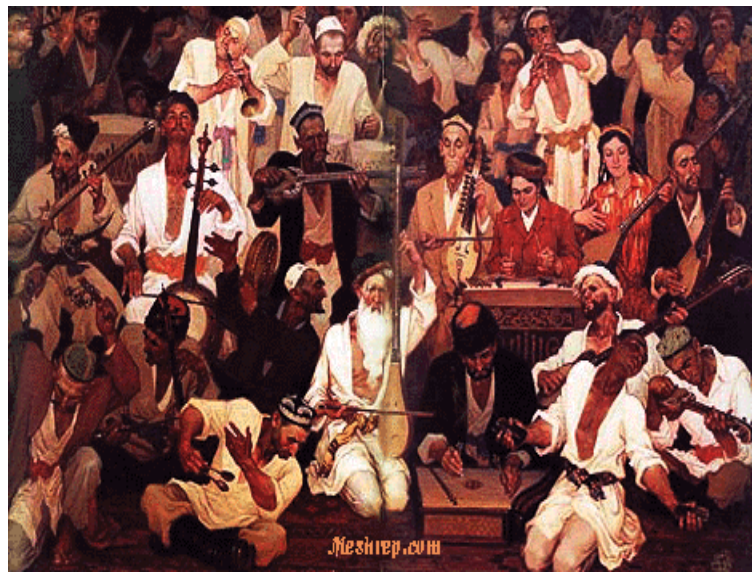

Figure 1. Ghazi Ahmet Uyghur Muqam

Uyghur Muqam, by Ghazi Ahmet, was painted in the 1970 's and is one of the first Uyghur paintings representing Uyghur cultural life. Figure 1 illustrates a Uyghur community practice that was well in abeyance by the time it was painted. There were other paintings about Xinjiang being exhibited in China, but ethnic Han Chinese artists had painted most of them.

Uyghur Muqam has been incorporated into the Uyghur scholastic curriculum - it appears in textbooks and on posters. This painting, in addition to featuring a subject well known to Uyghurs, shows many Uyghur objects. There are a variety of instruments, the rewap and the dutar; also the subjects wear regional clothing. Every man wears a doppa, a Uyghur hat. The men have similar shirts and the old men have beards. Nearly every Uyghur college students can recognize this painting.

The painter, Ghazi Ahmet, was born in March 1935 in Kashgar, Xinjiang and is only a decade older than the group of painters that produce the art of the current generation. $\mathrm{He}$ is vice chairman of the Regional Literature and Arts Union and a standing committee member of the Uyghur History and Culture Research Academy. In 1992 Prof. Ghazi was chief designer of building decorations for the Xinjiang Hall of the Beijing Great Hall of the People. He designed the large-scale wall carpet "Ode to Tengri Tagh" presented to the Beijing Great Hall of the People in 1988.

\section{3(c) the representation of women}

Female modesty and the legacy of 'protected women' are a major issue in the definition of Islamic liberalism and conservatism in any Muslim society. How and why the tradition of 'protected female' has come to play this important role in Muslim life has inspired some anthropological debate $[3,4]$.

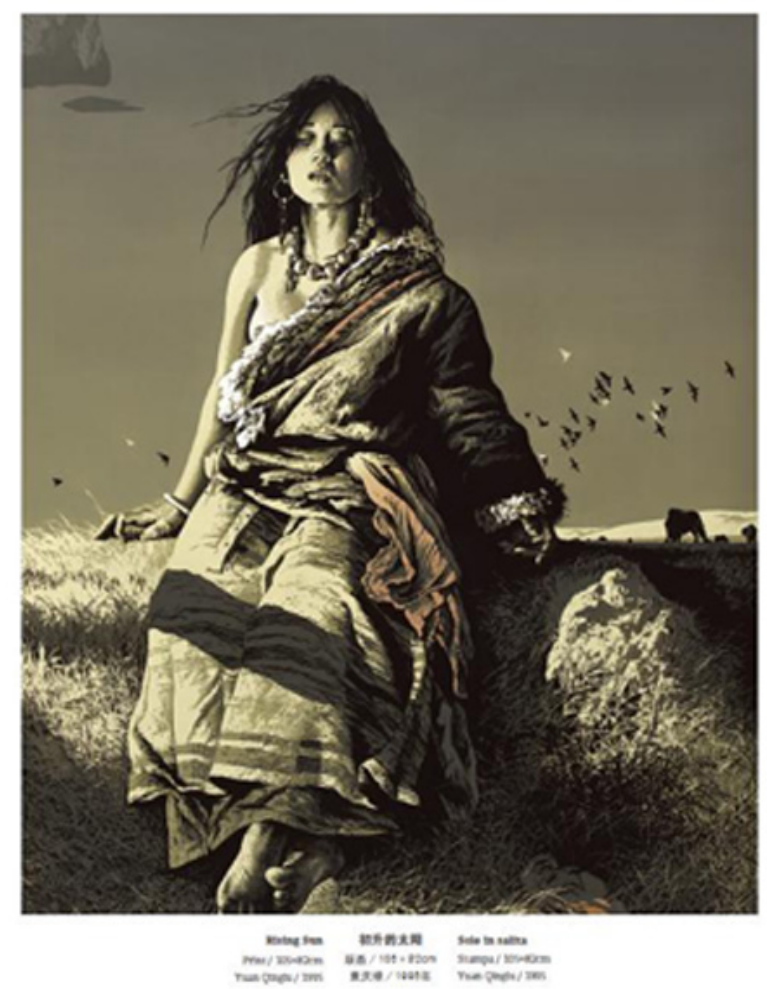

Figure 2. Ting Shaokuang, Silk Road

The portrayal of women in painting has been a critical point of issue as Uyghurs interact with Han Chinese. In a well-reported incident dealing with the art world that occurred nearly thirty years ago, but is just as relevant today, Ting Shaokuang, a Han Chinese artist, had his painting Silk Road (Figure 2), exhibited in the first major exhibit of Xinjiang-related art shown in the province.

From James Millward's report [11, p. 3] of the event: "In 1987, anthropologist Dru Gladney witnessed Uyghur artists protesting in Urumqi over an exhibition at the Overseas Chinese Hotel. The gallery had displayed Han Chinese paintings of Uyghurs singing, dancing, riding donkeys and balancing watermelons on their heads. Particularly offensive to many conservative Muslims was Ting Shaokuang's Silk Road, which depicted a woman bare-breasted with a desert caravan. Gladney analyzes this in [11, p.23]: The eroticization of minorities essentializes the imagined identity of the Han (ethnic Chinese) and reaffirms Han feelings of superiority. Public, state-sponsored minority representation as both more sensual and more primitive than the Han supports the state's agenda. (The Han Chinese believe that) with the proper educational and economic progress they will eventually attain the modernity that the Han have attained and enter into the same civilized restriction."

Seen twenty or thirty years later in 2013-2014, paintings of women are not shocking to college educated Uyghurs. 
Paintings such as Khariye Women (Figure 3) by Zoram Yasem, a well-known female Uyghur artist, win wide approval, but other paintings have raised issues in the community.

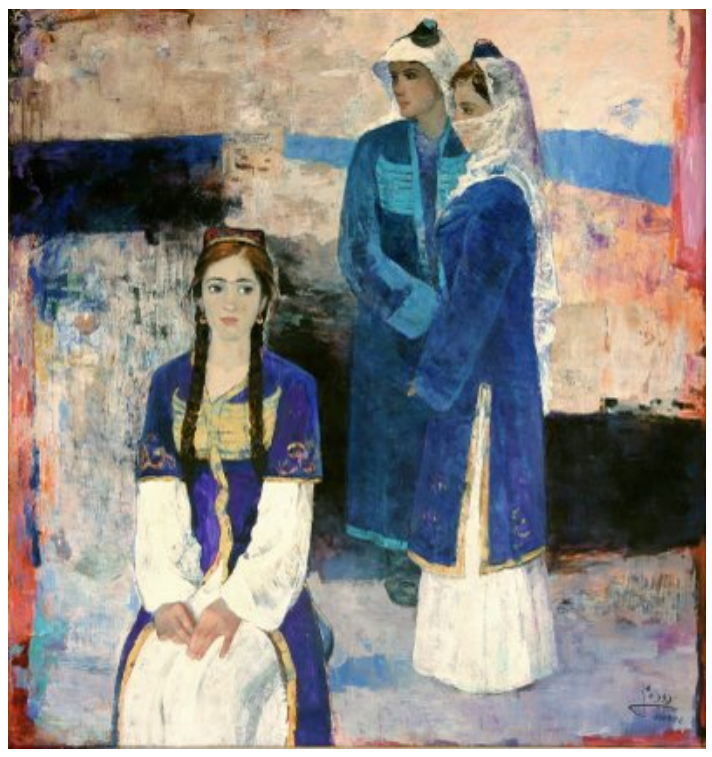

Figure 3 . Zoram Yasem Khariye Women

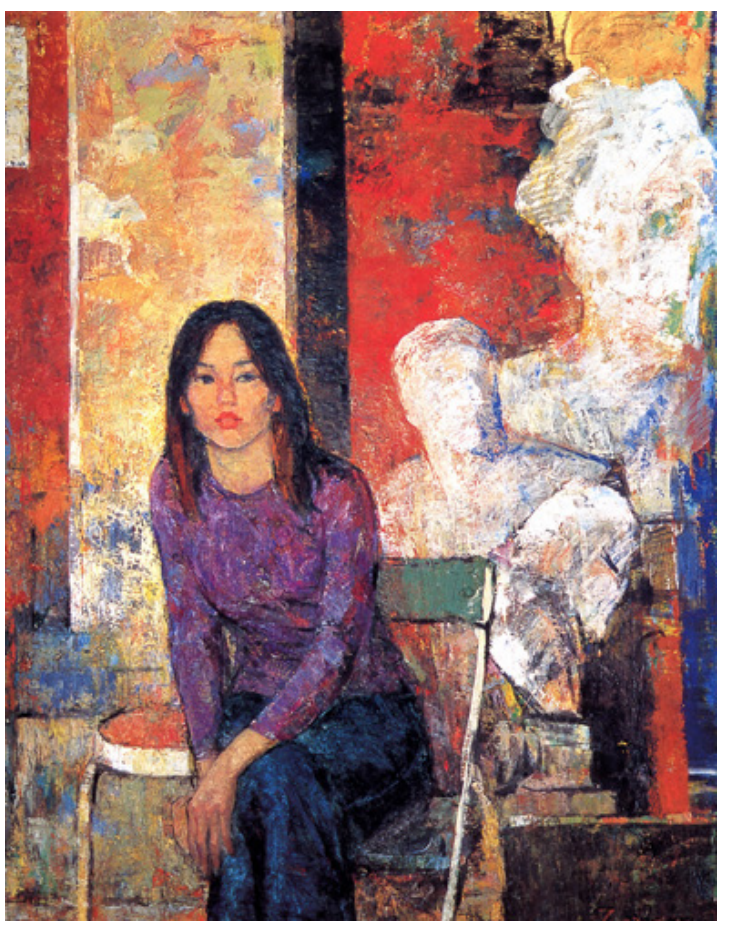

Figure 4. Zoram Yasem Uyghur Student

Figures 3 and 4, both by Zoram Yasem, represent alternative portrayals of Uyghur women. Zoram Yasem has a series of paintings in which women appear in a variety of clothing and settings. In Figure 3, although it is difficult to see, the doppa (head covering) is definitely there. In Figure 4, Uyghur Student, the woman appears in Western-style clothing with no head-covering at all. When a painting of a woman without any scarf, doppa, or dress characteristic of
Uyghurs is shown to Uyghur respondents some, especially young men from a conservative background, will respond that the woman in the painting is "not Uyghur, perhaps Russian".

On any visit to a Uyghur college campus or café or in cities such as Kashgar, Urumqi (the capitol of Xinjiang) or Beijing one can see young Uyghur women dressed in a completely Western fashion, very similar to the woman in the painting. The same students identify the Khariye Women as "real Uyghurs" even though almost no woman can be seen in Uyghur urban areas dressed in this fashion. Despite the seemingly obvious contradiction to reality in Uyghur students, both young men and women who identified a painting of the Western dressed woman, as "not Uyghur" wore no Uyghur clothes at all and dressed in an identical fashion to the woman in the painting

Zoram Yasem's background is interesting. She went to college in the 1970's, when higher education for women was rare, and then married. It was only after a divorce, also rare at the time, that she went to Japan and studied oil painting. She returned to Xinjiang to paint her series on women. [25, p 35].

Uyghur painting showed considerable development once art schools were established in Xinjiang, and the praise and criticism became much more public. The painter Ghazi Ahmet stands as an iconic figure in Uyghur art, but despite this he faced considerable criticism for a painting shown in Figure 5. Coming from a Uyghur tradition where the female body was not shown in a painting, Ghazi Ahmet's Uyghur Meshrep (Figure 5) is provocative. The painting itself is very well known. It was painted in 1978, was exhibited in Europe, and won prizes, but it still evokes criticism from college students who state that it is "not Muslim".

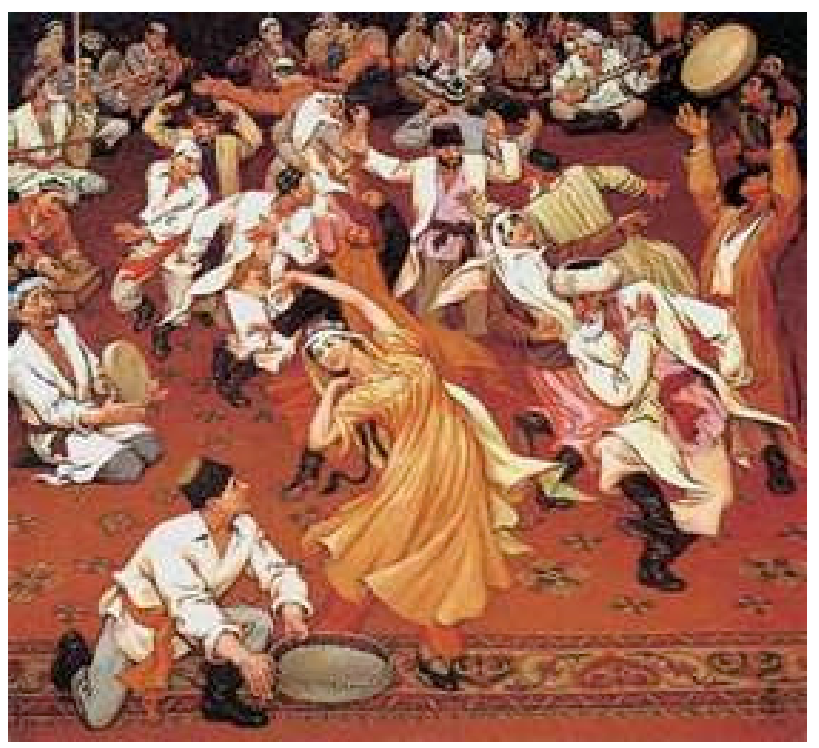

Figure 5. Ghazi Ahmet Uyghur Meshrep

Some of the students who saw Country Bazaar (Figure 6) by Mohammad Hay'it observed that all the men are sitting at one table and all the women are sitting at another. Several Uyghurs, aware of the fact that Westerners often say that 
there is discrimination in Muslim society against women, expressed an interesting qualification; perhaps these are groups of friends, all the men are friends and all the women are friends.

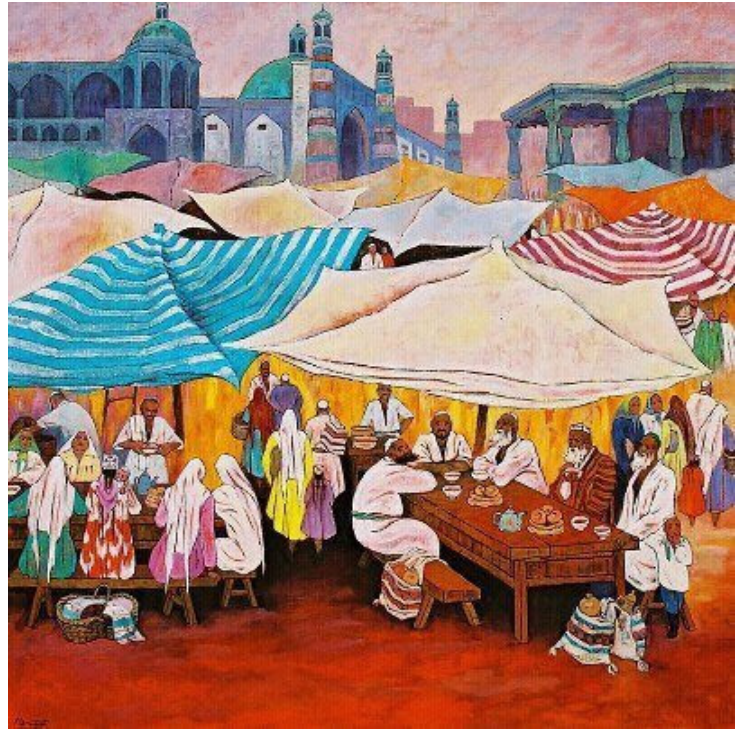

Figure 6. Mohammad Hay'it Country Bazaar

The point was then raised that if all the people were members of the same family, they would all sit at one table. It is true that in restaurants families sit together; the men do not sit at one table and the women at another.

One respondent, a graduate $\mathrm{PhD}$ student in Uyghur Language and Literature, made the point with some emphasis that the separation in the picture absolutely did not represent discrimination. "It is simply more convenient," he said, "for women to sit together at one table and men at another. A woman might be nursing an infant, for instance." He continued, "I went home to a wedding recently and all the men were in one room, and all the women were in another. Even that was not discrimination." Other students, usually young women, wee not so certain about that.

It is a fact that, when a Uyghur artist paints a scene in a 'public place' such as a bazaar, that scene is gender separated, at least at the current time.

Mohammed Hay'it's painting Uyghur Women (Figure 7) is part of the general movement among Uyghur painters to appeal to a secularist public, Uyghur, Western or Chinese. The striking pose of the woman wearing a form-fitting dress does not expose the woman's body, but it does represent a challenge to more traditional Uyghur Muslim culture. In contrast to her companions, the woman wears no head covering.

Hay'it is not alone in his challenge to Uyghur ideas about the appropriate presentation of women. One of the most controversial painters of Uyghur modernism is Abdulkirin Nasirdin, who has won European awards for his Uyghur paintings. Nasirdin, born in 1947 in Urumqi, studied art at the Minorities University of China.

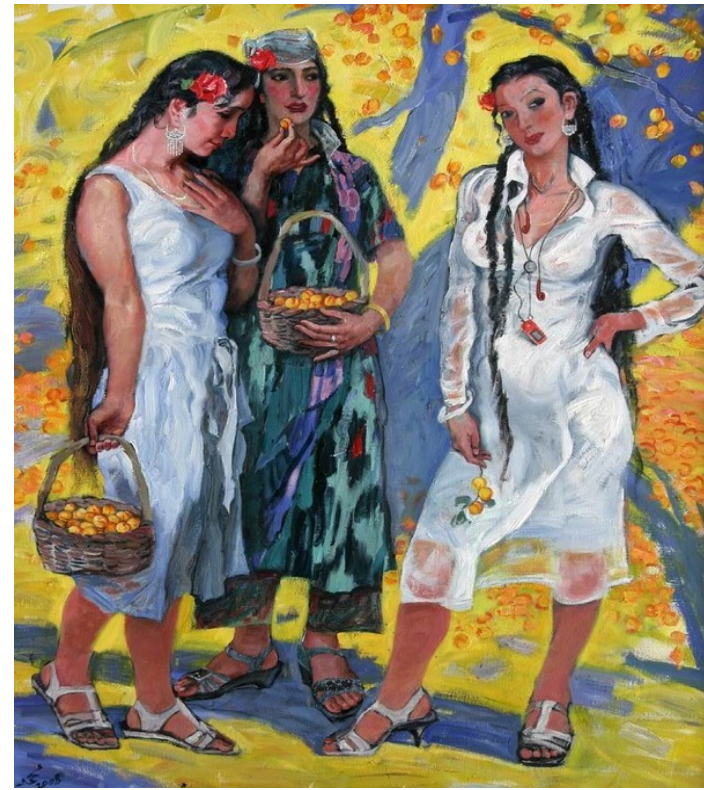

Figure 7. Mohammad Hay'it Uyghur Women

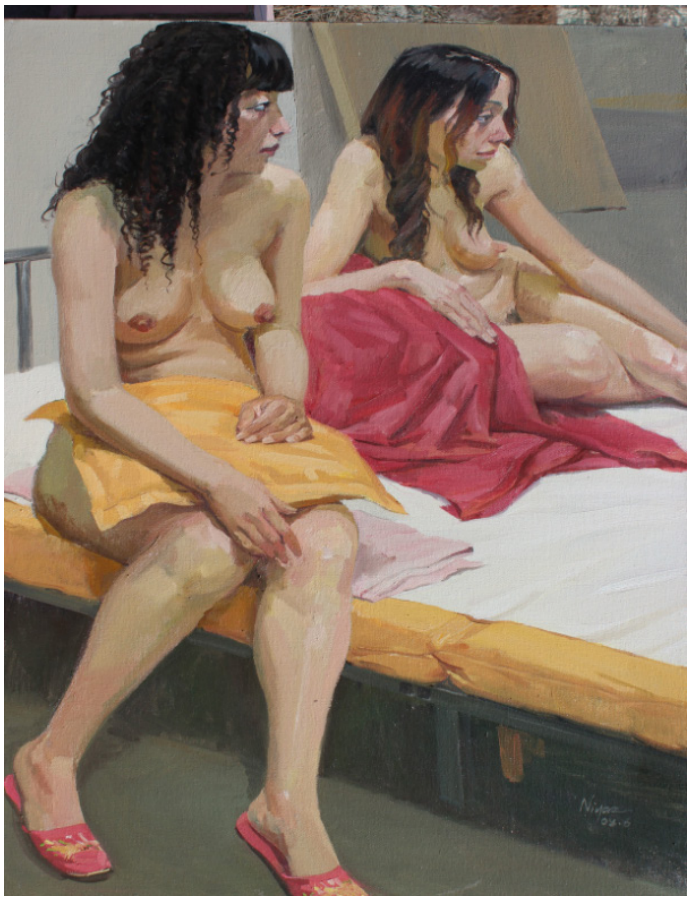

Figure 8. Abdulkerim Naserdin Nude Study

In 1978 his painting Dolan Meshrep (Dolan is another oasis city in Xinjiang) was shown in France, at the International Painting Gallery. Nasirdin also went to Japan to study Japanese techniques and later worked with the Chinese painter Zhong Wei. Cooperation with the Chinese is itself controversial, even though the market for paintings is largely Chinese [24 p. 63].

There are some issues raised here. A practicing Muslim, fairly educated, responded by saying that Abdulkerim Naserdin's experimentalism in paintings is entirely appropriate, even though he would not own a painting of a nude woman. 
Artist debate among themselves concerning the public appreciation of their art. Speaking about ventures in contemporary art in 2010, Yelkin Ghazi, son of Ghazi Ahmet said, "We cannot say that our people's level of enjoyment is low. We have a tradition of painting and enjoyment. Now if you have a painting in your home, you have money. A painting used to fetch 4000 -to- $5000 \mathrm{rmb}(\$ 600-\$ 900)$ and now it fetches 40,000 -to-50, $000 \mathrm{rmb}$. (\$6500-\$8500)" (Xinjiang Arts, 2010 p. 64). Modern Uyghur painters seem to be finding a market among Uyghurs.

\section{The Crisis in Uyghur Art Seen Through an Anthropological Lens}

There is a history of Uyghur art in pre-Muslim times with the Buddhist cave paintings at Dunhuang [6]. Uyghur art consistent with the Muslim traditions continued throughout the Islamic period. The alternative to 'modern art' was crafts [23], calligraphy [1, 20]), and miniatures [19], all consistent with Islamic tradition.

Into this mix entered, at the appropriate time, the artist in the modern sense of the term, as derived from Shiner and Bourdieu [18, 13]. The appropriate time was the post-1949 period in China. The successful artists were celebrated in museums and art schools, and their works appeared in Beijing, New York, and corresponding cities in Europe.

This 'modernity' construct $[18,13]$ has been previously presented as a general picture of development in Western Europe at the time of the growth of the middle class in the early nineteenth century. A 'Muslim modernity' framework is presented by the anthropologist Jessica Winegar for the artist in 1980's Egypt [23]. The artist and the work of the artist is placed "...at the intersection of culture and modernity..." and "... Egyptian modernism involves the selective adoption and repudiation of certain concepts of European modernity...but always through a process of translation that produces a 'difference' " [23, p.7; 17 p.2]

The net result of seeing art this way produces a vision of art in the midst of the Muslim awakening that covers a broad range of Muslim societies. This study is set far away in the eastern part of Central Asia, yet has a deep tie to events in the Middle East because there is a unity to the cultural experience. The product is an approach that is not a history of art in the Islamic world, such as the review of Wijdan Ali [2], but that of "an East-West bind facing Egyptian artists who produce work that is internationally recognized but locally grounded" [21 p.304]. This is a bind facing Uyghur artists as well.

In the development of Uyghur art, the choice of an 'identity' and a 'public' concerns the artists of Xinjiang although these are difficult issues to discuss. The choice of medium and subject matter represent another 'public' decision. Are artists addressing the Chinese and European public or are they speaking, culturally, to Uyghurs?

Winegar discusses the function that art played in the secular state and community. She notes [23, p.3] that the artists and their paintings served an important role for the leaders of the state in the period of secular republic under Nassar in the post-1945 world. Ramadan, summarizing Winegar: " In Egypt, the major goals at the time remain central to the Ministry's mission today: to define the nation and national identity; to protect cultural patrimony; and to uplift the so-called masses by exposing them to the arts." [17, p.3] Today the secular rulers, the new monarchs are anxious to establish the identity of their subjects by celebrating the 'national' rather than the 'Islamic' part of the cultural tradition. These new secular leaders are typically military figures quite anxious to promote their regime as the legitimate representative of a national cause.

Similarly, the leadership of the Chinese Communist Party has been and remains quite anxious to present itself as representing a Chinese and Uyghur cultural unity. In China, this is called the 'national' question and its origins go back to the revolutionary period and the writings of Mao Zedong. One favored vehicle for establishing this vision of a unified Chinese and Uyghur culture is through education and the development of arts consistent with the peaceful relations of Chinese and Uyghurs. Government support for Uyghur Muqam by Ghazi Ahmet, and its distribution in Uyghur textbooks is one example of this process.

Despite the fact that artists in China, just as those in the Middle East, may underplay their connection to state institutions, this is a definite part of their artistic output. Artists are anxious to establish their reputations in Xinjiang and China in attempt to win support at home as well as abroad. They eagerly compete to gain the favor of state institutions. As prizes are awarded and as art schools are established, the favored posts go to the artists that have been discussed, and to the newer generation of Uyghur artists. Nimrod Baranovitch [5, p.747] has pointed out in his study of Uyghur popular musicians the artists are often anxious to present apolitical songs or recordings, since the artists want to be valued for their work. Taking this observation about music to the world of the visual arts, the artists citied might prefer to minimize the functional tie between their works and the aims of the Chinese government.

Now, when the success of the initial group of modern Uyghur artists seems assured, the question that dominates Egyptian art is felt in Xinjiang as well. What is the audience of the artist? Is it the secular leaders of the nation? Is it the European arts community that awards prizes and prestige, and allows the artists access to European-style galleries in their home country? Is their audience the Han Chinese public and art investors? Is their audience the Muslim public, which may not understand or appreciate their work? The tensions of the beginnings of modernism in Egypt in the colonial period, and in China, under the Communist Party, continue to be felt at throughout the public world. The curriculum in art schools is concerned with creating authentic national subjects that demonstrate the loyalty and pride that Uyghurs should feel towards developments in Xinjiang. Winegar extensively discusses the dilemma that many Egyptian students feel as a result of receiving training that is almost entirely based on a Western model but that stresses the importance of producing 
work "authentically Egyptian." [19, p.120]

The artists and the impact of their art are decidedly liberal and anti-fundamentalist. The choice of medium, oil painting, involves "Uyghur subject matter and Western and Chinese techniques", as one professor stated. The artists, understand there is a danger that the new Uyghur art may be too far away from contemporary Uyghur culture. In the discussion concerning Uyghur art [25 p.64]. One modern artist, Turdi Amin, maintained that there is no Uyghur 'painting style' now, only Uyghur painters. Yelkin Ghazi pointed out that are no Uyghur museums; there are some galleries, people rent a space, but otherwise there are almost no means of exhibiting one's work. Yelkin Ghazi also pointed out that there are no copyright laws. Restaurants will hang paintings on walls, but no one ever asks permission from the painter. On the positive side, Zoram Yasem said "previously people would decorate their home by buying carpets, but now people purchase paintings. Some people have some extra money, but most in Xinjiang have no money, and most cannot understand a painting. There is a real problem." [25 p.63].

As a practical matter the painters, though some are personally successful, are challenged by contemporary cultural developments. The initial victory, the establishment of a modern Uyghur art, has been won. In the age of post modernization, conservative Islam has launched a counter-offensive against their initial success.

\section{REFERENCES}

[1] Ayit, Adiljahn 2013 Uyghur hettatli (ch) unung otmushi ve hazirchi ehvali toghrusida (About the Past and Present State of Uyghur Calligraphy) Xinjiang Arts 4:23-27.

[2] Ali, Wijdan 1977 Modern Islamic Art: Development and Continuity. Gainesville. University of Florida Press

[3] Abu-Zahra, Nadia 1970. On the Modesty of Women in Arab Muslim Villages, a Response. American Anthropologist, New Series, 72:5 (October), 1079-1088.

[4] Antoun, Richard 1968. On the Modesty of Women in Arab Muslim Villages. American Anthropologist (70) 671-697.

[5] Baranovich, Nimrod 2003 From Margins to the Centre: the Uyghur Challenge in Beijing. China Quarterly 175 (September), 726-750

[6] Michael Brose 2004 Review of Uygur Patronage in Dunhuang: Regional Art on the Northern Silk Road in the Tenth and Eleventh Centuries Lilla Russell-Smith Leiden, Netherlands, Brill 2004. Journal of Asian Studies. Uyghur patrons influenced Dunghuang 621-623

[7] Eastman, Alvan C. 1933 Islamic Miniature Painting Parnassus . Volume 5 Number 7 December pages 22-23 + 30 .

[8] Harris, Rachel and Dawut, Rahilla 2002 Mazar Festivals of the Uyghurs: Music, Islam and the Chinese State." British Journal of Ethnomusicology, 11(1) 101-118
[9] Harris, Rachel 2007 "Turkestan Chinois. Le Muqam des Dolan: Musique des Ouigours du desert de Taklamakan/ Chinese Turkestan. Music of the Uighurs from the Takalmakan Desert by Naïve; P. Bois; M. Mijit; F. Kane.” Yearbook for Traditional Music, Vol. 39, pp. 191-192.

[10] Makofsky, David 2013 The Artist and the Artisan in Xinjiang (China) Central Asia: the changing Uyghur Moslem culture European Journal of Applied Social Sciences Research June 1 (1) 29-34.

[11] Millward, James 2011 Art Music and the Ambiguities of Chinese Silk Roadism in Xinjiang. Silk Road Foundation Newsletter. 3(1), 1-10

[12] Moaddel, Monsoor. 1999 Religion and Women: Islamic Modernism vs. Fundamentalism" Journal for the Scientific Study of Religion 37:1 108-130

[13] Mudimbe , Vincent 1993 Reading and Teaching Pierre Bourdieu. Transition 61, 144-160

[14] Pahwa, Sonali and Winegar, Jessica 2012 Culture, State and Revolution Volume 42 (Summer) Middle East Research and Information Project MER 263

[15] Pew Global Attitudes Project, 2006 The Great Divide: How Westerners and Muslims View Each Other, Philadelphia, PA

[16] Pew Global Attitudes Project 2012 The Global Religious Landscape A Report on the Size and Distribution of the World's Major Religious Groups as of 2010 Philadelphia, PA

[17] Ramadan, Dina 2008 The Formation of the Artist within a Contested Terrain: The Politics of Artistic Production in Mubarak's Egypt . Review of Winegar (2006) Art Journal 67:1 spring pp.119-121.

[18] Shiner, Larry 1975 Tradition /Modernity: An Ideal Type Gone Astray. Comparative Studies in Society and History, $17(2)$, pp. $245-252$

[19] Schimmel, Annemarie and Rivolta, Barbara 1992 Islamic Calligraphy The Metropolitan Museum of Art Bulletin New Series, Volume 50 Number 1 Summer pp. 1+3-56.

[20] Torsun, Nurbiye, and Makofsky,David 2013 Mihnettin Kelgen Hikmet (From Effort You Get Something Valuable). Zhongguo Milletliri, June (6) Number 151 pp54-58.

[21] Winegar, Jessica 2000 International Journal of Middle East Studies 32:2 May, 304-306 review of Liliane Karnouk's Modern Egyptian Art: The Emergence of a National Style American University of Cairo Press, Cairo

[22] Winegar, Jessica 2006 Creative Reckonings: Politics of Art and Culture in Contemporary Egypt Stanford: Stanford University Press

[23] Winegar, Jessica 2008 The Humanity Game: Art, Islam, and the War on Terror Anthropological Quarterly, Volume 81, Number 3, Summer pp. 651-681

[24] Wussiman, Mahire and Makofsky, David 2013 Qeshqerdiki Qol Hunerwenchilikning Hazirqi Ehwali Handcraft business in Kashgar at present) Zhongguo Milletliri, June (6) Number 149 pp 28-31. 
[25] Xinjiang Arts

Resimlerimiz Nime Deydu? (What Do Our Artists Say?) 2010:1

Group Discussion pp.60-65.

Abdulkerim Naserdin, 2010, pp.4-6.

Muhtar Yasin 2012:1 pp5-7.

Zoram Yasem. 2012:1 p.35. 